\title{
PERAN TEKNOLOGI KOMUNIKASI \\ DALAM INTERAKSI AYAH DAN ANAK STUDI KASUS: INTERAKSI AYAH DAN ANAK MELALUI SMARTPHONE
}

\author{
Detania Savitri \\ Departemen Sosiologi Universitas Indonesia \\ detaasavitri@yahoo.com
}

\begin{abstract}
Function of a father is to support the finance of his family, while the mother functions as a nurturer for the child. A father that works full time will have his interaction with his child diminished. On the other side, communication technology has been developed to facilitate the interaction of individuals. This research aims to uncover if smartphones can increase the intensity and closeness of interaction between father and his children. Also, this research aims to know iffathers can socialize on his children through smartphones by controlling daily activities of the children. This article uses functionalism perspective. The author used qualitative approach by interviewing three fathers and three children aged 20 and up that currently use smartphones and residing in the city of Depok. The author finds that smartphones can alter the interaction between father and his children, and the father can provide social control to the children in interaction through smartphones. In interaction between father and children, smartphones can also be used father to socialize norms and values to his children in his interaction.
\end{abstract}

\begin{abstract}
Abstrak
Fungsi ayah dalam keluarga adalah sebagai pencari nafkah untuk memenuhi kebutuhan keluarga, sementara ibu berfungsi dalam mendidik anak. Ayah yang bekerja penuh waktu akan berkurang interaksinya dengan anak. Disisi lain, teknologi komunikasi diciptakan untuk mempermudah interaksi antar individu. Penelitian ini ingin mengetahui apakah smartphone dapat meningkatkan intensitas kedekatan interaksi antara ayah dan anak. Selain itu, penelitian ini juga ingin mengetahui apakah ayah dapat memberikan sosialisasi kepada anak melalui smartphone dan mengontrol keseharian anak. Artikel ini menggunakan perspektiffungsionalis. Pendekatan kualitatif digunakan oleh penulis dengan mewawancarai tiga ayah dan tiga anak berusia 20 tahun ke atas yang samasama menggunakan smartphone di kota Depok. Temuan yang diperoleh penulis yaitu smartphone dapat merubah interaksi ayah dengan anak, dan ayah dapat memberikan kontrol sosial kepada anak dalam interaksi melalui smartphone. Dalam interaksi ayah dan anak, smartphone juga dapat digunakan ayah untuk mensosialisasikan nilai-nilai kepada anak.
\end{abstract}

Keywords: Family, Technology, Interaction 


\section{PENDAHULUAN}

Berdasarkan Hidayati, dkk (2011), tugas ayah di dalam keluarga adalah sebagai pencari nafkah, sementara ibu mendidik anak. Ayah berperan sebagai economic provider untuk memenuhi kebutuhan keluarga dengan melakukan aktivitas mencari nafkah, bahkan juga kerja sampingan di hari libur kerja (Hidayati, dkk, 2011). Menurut Fatherhood Forum, hal ini membuat adanya anggapan bahwa parenting hanya di urus oleh ibu, sementara ayah tidak perlu berperan dalam pengasuhan anak. (http://fatherhood.id/ tentang-kami/: Sabtu, o5 Desember 2015 pukul 09.15 WIB). Menurut studi Mason dan Kuhlthau (1989) dalam Eshleman (2003: 350), dikatakan bahwa ayah dianggap tidak penting dalam proses pengasuhan karena ayah cenderung terlalu sibuk, acuh tak acuh, atau tidak kompeten untuk menjadi orang tua yang baik. Ketika ayah hanya berperan dalam economic provider saja, maka keluarga khususnya anak akan kehilangan sosok ayah atau Fatherless Generation. (Mason dan Kuhlthau (1989) dalam Eshleman, 2003: 350). Peran ayah yang fokus dalam mencari nafkah dan menghabiskan banyak waktu diluar rumah membuat interaksi dengan anak menjadi berkurang.

Disisi lain, berkembangnya teknologi informasi dimaksudkan untuk mempermudah interaksi antar individu, salah satunya yaitu smartphone (Putra, 2014: 1). Smartphone merupakan telepon genggam yang memiliki kemampuan tingkat tinggi dengan fungsi menyerupai komputer (Putra, 2014). Perkembangan media teknologi smartphone ini sesuai dengan kebutuhan para pengguna, termasuk dapat berpengaruh terhadap kegiatan interaksi sosial dari pengguna smartphone itu sendiri (Putra, 2014). Tulisan ini ingin menjelaskan tentang perkembangan teknologi informasi khususnya smartphone yang memungkinkan dalam membantu interaksi anak dengan ayah yang sibuk berkarir untuk mencari nafkah keluarga. Pertanyaan utama yang ingin dijawab dalam penelitian ini adalah apakah smartphone berpengaruh pada intensitas interaksi antara ayah dan anak?
Dengan aktivitas mencari nafkah, menjadi berkurang fungsi sebagai ayah (Astuti dan Puspitarani, 2013). Hal ini bisamemberi dampak yang buruk bagi anakanak, yaitu terganggunya perkembangan anak (Maharani dan Andayani, 2003). Dalam studi tentang ayah di Amerika Serikat yang dilakukan oleh Amato (1994) dan Eggebeen, dkk (2001) dalam Eshleman (2003: 350) ditemukan bahwa figur ayah penting dalam kehidupan anak-anaknya. Interaksi antara ayah dan anak lebih banyak dilakukan ketika ayah memiliki waktu luang dan ketika hari liburdengan melakukan aktivitas bersama seperti menonton televisi, jalan-jalan, dan bermain bersama (Hidayati, dkk, 2011: 5). Menurut hasil survei yang dilakukan oleh Bronfenbrenner dalam Hidayati, dkk, 2011: 6) ditemukan bahwa rata-rata waktu yang digunakan ayah untuk anak adalah sekitar 15-20 menit dalam sehari. Dengan demikian, hubungan yang baik dan berkualitas antara anak dan ayah merupakan situasi penting bagi anak (Hidayati, dkk, 2011).

Artikel-artikel jurnal sebelumnya melihat interaksi antara ayah dan anak berlangsung secara face to face atau interaksi secara fisik ketika ayah dan anak bertemu. Biasanya ayah dan anak melakukan interaksi ketika ada kegiatan bersama, ketika hari libur, dan hanya dengan jumlah waktu yang terbatas. Artikel ini ingin mengetahui apakah perkembangan teknologi smartphone memberikan perubahan interaksi antara ayah dan anak pada periode waktu ayah sedang bekerja. Walaupun ayah bekerja dan tidak bertemu fisik dengan anak, interaksi melalui smartphone dapat membuat ayahmemberikan kontrol kepada anak. Melalui kontrol sosial yang dilakukan ayah kepada anak, apakah ayah juga dapat memberikan sosialisasi kepada anak melalui interaksi menggunakan smartphone.

\section{METODE}

Artikel ini menggunakan pendekatan kualitatif, karena ingin mendeskripsikan lebih detail terkait isu pengaruh teknologi komunikasi smartphone dalam interaksi ayah dan anak. Pengumpulan data dengan 
qualitative interviewing atau wawancara mendalam (Bryman, 2004) dilakukan padatiga ayah yang bekerja dan tiga anak perempuan yang menggunakan smartphone. Biasanya seorang anak perempuan lebih dekat dengan ayah dibandingkan dengan ibunya. (http://citizen6.liputan6.com/ $\mathrm{read} / 2285016 / 6$-alasan-anak-perempuanlebih-dekat-dengan-ayahnya, Minggu 27 Desember 2015 pukul 20:13 WIB).

Penulisjuga menggunakan studi literatur dari artikel-artikel jurnal yang relevan dengan isu interaksi ayah dan anak melalui smartphone. Kriteria informan dalam tulisan ini adalah ayah bekerja dan anak berusia 20 tahun keatasyang menggunakan smartphone di kota Depok. Menurut psikolog anak Universitas Indonesia yang bernama Dra. Mayke S Tedjasaputra Msi, minimal anak berusia 10-11 tahun atau lebih baik setelah anak duduk di bangku Sekolah Menengah Pertama karena akan lebih mudah diberikan pengertian serta telah mengetahui untuk kepentingan tertentu (http://yogyakarta. tarakanita.or.id/artikel/2015/o4/22/waktuyang-tepat-anak-boleh-menggunakanhandphone-4dd5ae45.html, Minggu 27 Desember 2015 pukul 20.26 WIB). Anak yang berusia 10 tahun kebawah menurut Dr. Joe Austerman dari Cleveland Clinic Children's, belum cocok untuk memiliki smartphone. (http://lifestyle.analisadaily. com/read/usia-terbaik-anak-menggunakansmartphone/1560o8/2015/o7/30, Minggu 27 Desember 2015 pukul 20.29 WIB). Dengan demikian, anak yang berusia 20 tahun keatas tersebut mudah untuk berinteraksi dengan ayah dan sedang berada dijenjang Perguruan Tinggi yang menyebabkan terbatasnya waktu untuk berinteraksi dengan ayah.

\section{HASIL DAN PEMBAHASAN}

\section{Perspektif Fungsionalis Dalam Keluarga}

Klein dan White (2007: 37) menjelaskan bahwa Parsons menghasilkan berbagai karya terkait keluarga, sosialisasi dan proses interaksi. Dalam Klein dan White (2007: 34), keluarga dikatakan seperti organisasi sosial, karena keluarga berfungsi yang mana didalamnya terdapat struktur organisasi yang hirarkis. Struktur organisasi sosial yang hirarkis dalam keluarga adalah ayah, ibu, dan anak.Sebagai sebuah organisasi sosial, keluarga berfungsi dalam hal memenuhi kebutuhan individu atau kebutuhan masyarakat. Pendekatan fungsionalis dalam keluarga mengutamakan adanya harapan sosial dari fungsi keluarga. Pemahaman ini memerlukan keberadaan ayah dalam interaksinya dengan anak-anak melalui smartphoneagar dapat berfungsiyang bermanfaatbagianak. Perspektiffungsionalis lebih melihat bagaimana sesuatu bekerja, bukan mengapa sesuatu ada.

Artikel ini menggunakan konsep struktur dalam perspektif fungsionalis yang menjelaskan adanya hubungan antar individu dalam suatu kelompok, yaitu keluargakhususnya dalam pola perilaku dan interaksi (Klein dan White, 2007: 44). Pola hubungan dalam bentuk interaksi antara keluarga, khususnya ayah dan anak, akan tetap berjalan melalui smartphone ketika ayah dalam periode waktu bekerja. Selain itu, konsep sistem juga digunakan dalam artikel ini, karena pola hubungan dalam bentuk komunikasi atau interaksi antara ayah dan anak merupakan cerminan adanya tingkat (hirarki) untuk saling melengkapi (Klein dan White, 2007: 46). Sebagian besar Parsons mengkhususkan pemikirannya mengenai sistem sosial. Parsons dalam karyanya mengenai keluarga mencakup proses sosialisasi yang diperlukan untuk individu dalam mengintegrasi dirinya ke dalam kelompok atau sistem sosial.

Menurut Parsons dalam Klein dan White (2007:37), proses sosialisasi merupakan salah satu fungsi dasar keluarga. Proses sosialisasi ini bertujuan untuk menghasilkan aktor sosial yang diciptakan oleh orang lain, dalam hal ini keluarga. Proses sosialisasi terlibat dengan sistem hubungan atau interaksi antara anggota individu dalam keluarga (Klein dan White, 2007:39). Menurut Soe'oed dalam Ihromi (2004: 32), proses sosialisasi dapat dilakukan dalam jarak tertentu melalui sarana media. Dalam artikel ini, sarana media yang dilakukan untuk proses 
sosialisasi adalah interaksi melalui teknologi komunikasismartphone ketika ayah berada pada periode waktu bekerja. Parsons juga berpendapat bahwa setiap sistem harus mampu untuk memenuhi tujuan dari sistem dan mampu untuk mengintegrasikan anggotanya (Klein dan White, 2007: 37).

Perspektif fungsionalis menurut Parsons dalam Klein dan White (2007: 46) juga membahas mengenai konsep norma yaitu bertanggung jawab atas kontrol sosial yang mewujudkan ketertiban yang berasal dari interaksi antara individu, dalam hal ini interaksi antara anggota keluarga. Parsons dalam Klein dan White (2007: 46) juga mengemukakan bahwa norma merupakan aturan-aturan sosial yang mengatur perilaku manusia. Sehingga dalam interaksi ayah dengan anak, dapat menimbulkan kontrol sosial yang menciptakan aturan-aturan sosial dalam mengatur perilaku anak. Parsons melihat keluarga sebagai lembaga sosialisasi yang penting melalui individu untuk mempelajari aturan-aturan dalam suatu sistem sosial tertentu (Klein dan White, 2007: 47).

Sementara, konsep nilai dalamperspektif fungsionalis juga digunakan dalam artikel ini terkait nilai-nilai yang digunakan ayah dalam mengontrol perilakuanakyang munculdalam suatu ekspresi budaya interaksi individu. Nilai-nilai tersebut terinternalisasi dalam kepribadian anak yang mempengaruhi peran anak dalam suatu sistem sosial. Sosialisasi nilai-nilai seperti ide-ide tertentu, sikap, dan berbagai hal yang muncul dari interaksi yang dilakukan oleh anggota keluarga, dalam hal ini ayah dan anak, menjadi motif untuk mengikuti norma-norma dan melakukannya dalam sistem sosial (Klein dan White, 2007: 47).

Dengan demikian, artikel ini menggunakan perspektif fungsionalis menurut Parsons yang didalamnya terdapat konsep struktur, sistem, norma, dan nilai untuk menjelaskan interaksi antara anak dan ayah melalui smartphone yang menimbulkan suatu kontrol sosial dan sosialisasi. Dengan demikian, peneliti menggunakan perspektif fungsionalis ini untuk menjelaskan fungsi ayah dalam keluarga berdasarkan interaksi ayah dan anak melalui smartphone.

\section{Teknologi Informasi}

Grant dan Meadows (2008: 1), manusia dikelilingi oleh teknologi komunikasi yang sangat penting untuk menjalin hubungan interpersonal. Teknologi komunikasi merupakan sistem saraf masyarakat kontemporer, dan mengontrol unit-unit yang saling bergantung. Dalam Mirabito dan Morgenstern (2004: 108), telepon selular merupakan salah satu perlengkapan dalam komunikasi yang digunakan untuk layanan komunikasi pribadi. Teknologi komunikasi ini menurut peneliti dapat digunakan untuk membantu ayah dan anak dalam menjalin hubungan secara interpersonal, khususnya melalui smartphone. Teknologi komunikasi smartphone digunakan ayah untuk mengontrol dan memberikan sosialisasi kepada anak dalam interaksinya.

Grant dan Meadows (2008: 2) juga menjelaskan bahwa teknologi komunikasi dipandang sebagai alat yang membuat lebih efisien dalam berinteraksi. Penelitian ini ingin membuktikan apakah teknologi komunikasismartphone membuat interaksi antara ayah dan anak menjadi lebih efisien. Dengan demikian, jarak geografis tidak lagi menghambat hubungan interaksi antara ayah dan anak melalui smartphone karena kekuatan teknologi komunikasi dapat menjembatani interaksi interpersonal.

\section{Perubahan Interaksi Ayah dan Anak Melalui Smartphone}

Dalam hasil penelitian, ditemukan bahwa terjadi perubahan pola hubungan antara anak dan ayah dengan melihat intensitas interaksi yang terjadi. Ketika ayah dan anak telah menggunakan smartphone, teknologi komunikasi sangat berkontribusi pada perubahan interaksi ayah dan anak yang membuat mereka dapat berinteraksi tanpa bergantung pada interaksi secara langsung. Sebelum ayah dan anak menggunakan smartphone, pola hubungan mereka terjadi melalui perantara ibu atau handphone 
ibu. Sementara, setelah ayah dan anak menggunakan smartphone, tidak lagi terjadi interaksi melalui perantara ibu sebagai mediasi. Namun, interaksi tersebut terjadi secara langsung melalui smartphone pribadi anak.

Dalam kesehariannya, ayah fokus dalam mencari nafkah untuk memenuhi kebutuhan keluarga. Sebagian besar, ayah menghabiskan waktunya untuk bekerja sejak pukul 07.0o WIB hingga sore bahkan malam, yang tidak menentu jam pulang kerjanya. Dengan kondisinya yang fokus dalam mencari nafkah dan bekerja penuh waktu, ayah menjadi jarang untuk bertemu dengan anak di rumah. Terkadang ketika anak belum bangun dari tidurnya, ayah sudah berangkat untuk bekerja, dan terkadang anak sudah tidur sebelum ayah pulang bekerja. Hal seperti ini salah satu alasan mengapa ayah dan anak menjadi jarang bertemu dan secara tidak langsung membuat interaksi mereka menjadi berkurang.

Sebelumanak menggunakan handphone atau smartphone, biasanya ayah menanyakan keadaan anak melalui handphone ibu. Demikian pula halnya dengan anak, sebelum anak memiliki handphone terkadang anak juga menggunakan handphone ibunya untuk berbicara dengan ayah. Sebagian besar, anak sudah diberikan handphone ketika mereka duduk di Sekolah Menengah Pertama (SMP). Dengan diberikannya handphone ketika SMP, membuat anak dapat secara pribadi berinteraksi dengan ayah ketika ayah sedang bekerja, khususnya melalui telfon dan SMS. Namun,ketika anak sudah memiliki handphone saat SMP, ayah tetap jarang menghubungi anak. Hal ini membuat ayah dan anak menjadi tidak dekat seperti kedekatan anak dengan ibu yang memang dirumah.

Mengikuti perkembangan teknologi komunikasi dengan terciptanya telfon pintar atau yang biasa disebut sebagai smartphone, ayah mampu memberikan alat komunikasi tersebut untuk anaknya. Smartphone dengan aplikasi-aplikasi instant messenger seperti Blackberry Messenger, dan Whatsapp digunakan oleh ayah dan anak untuk berinteraksi. Antara anak dan ayah mengaku bahwa dengan menggunakan smartphone membuat interaksi antara mereka menjadi lebih sering daripada sebelum menggunakan smartphone. Hal ini didukung dengan apa yang dikatakan oleh informan NN pada hari Selasa, 8 Desember 2015, menggunakan smartphone memberikan kemudahan dan kecepatan dalam komunikasi. Sementara menurut informan YM pada hari Jumat, 4 Desember 2015, interaksi dengan anak menjadi sering dengan menggunakan smartphone karena anak sangat aktif dalam menggunakan instant messenger. Pada awalnya, ayah dan anak sangat terbatas dalam hal bertukar informasi, tetapi saat ini dengan adanya smartphone membuat ayah dan anak kapan saja dapat bertukar informasi.

$$
\text { Aplikasi instant messenger }
$$

yang banyak digunakan oleh anak dan ayah dalam berinteraksi yaitu aplikasi Whatsapp. Biasanya hampir setiap hari ayah menghubungi anak melalui whatsapp dan juga telfon yang menghabiskan waktu sekitar 5 hingga 15 menit. Dalam sehari terkadang ayah menghubungi anak melalui smartphone dalam waktu sekali, dua kali atau bahkan berkali-kali. Begitupula yang terjadi pada anak, anak selalu menggunakan smartphone untuk menghubungi ayahnya. Terkadang anakyanglebihsering menghubungiayahnya, atau bahkan antara anak dan ayah sama-sama sering menghubungi. Perubahan interaksi dengan adanya smartphone ini membuat anak tidak hanya memiliki hubungan dengan ibu, tetapi juga bisa berhubungan dengan ayah ketika ayah sedang bekerja.

Dengan menggunakan smartphone, anak dapat secara langsung menghubungi ayahnya apabila anak merasa membutuhkan ayah ketika sedang bekerja. Menurut informan NNpada hari Selasa, 8 Desember 2015, ketika ia mengalami kesulitan untuk memilih sesuatu dengan waktu singkat dan merasa membutuhkan saran dari ayah, ia tidak lagi harus menunggu untuk bertemu ayahnya dirumah, tetapi bisa bertanya kepada ayah melalui smartphone. Seperti yang dikatakan oleh informan NN pada hari Selasa, 8 Desember 2015 di FISIP UI: 
"Kadang juga tiba-tiba suka butuh saran dari ayah sih. Misalnya waktu itu lagi periode pengisian IRS ya. Terus ada mata kuliah yang muncul dan itu harus rebutan. Saya ngerasa bingung sebenernya buat pilih mata kuliah apa dan nanya-nanya sama ayah saya terkait hal itu karena saya berpikir kalau ayah saya lebih mengerti. Karena kalau saya hubungin ibu saya, pasti beliau tidak paham. Langsung aja pas itu saya kirim chat lewat whatsapp ke ayah saya..."

Selain itu, sebagian besar anak mengirimkan pesan kepada ayah melalui smartphone untuk meminta sesuatu, seperti makanan, atau bahkan meminta uang. Sementara terkadang dengan smartphone ayah juga menghubungi anak untuk meminta saran terkait suatu hal yang cukup penting.

Pemanfaatan smartphone yang digunakan oleh ayah dan anak tidak lepas untuk berinteraksi dengan orang lain. Informan YM, SA, dan UR mengaku bahwa mereka menggunakan smartphone juga untuk keperluan bekerja, seperti akses yahoo, gmail, browsing ataupun chat group bersama kerabatnya. Begitupula untuk informan TS, LS, dan NN seorang mahasiswa yang memanfaatkan smartphone untuk keperluan perkuliahan. Selain memanfaatkan smartphone untuk keperluan bekerja dan perkuliahan, mereka juga mengaku memanfaatkan smartphone untuk saling berinteraksi. Beberapa informan mengatakan masih lebih sering berinteraksi secara face to face, namun informan lainnya mengatakan bahwa lebih sering interaksi menggunakan smartphone antara ayah dan anak. Dengan demikian, smartphone dengan aplikasiaplikasinya membantu menjalankan pola hubungan antar ayah dan anak dalam hal interaksi.

Smartphone yang digunakan ayah dan anak merupakan teknologi komunikasi yang dapat menjalin hubungan interpersonal (Grant dan Meadows, 2008: 1). Pada awalnya, ayah yang bekerja sulit untuk berinteraksi dengan anak. Hal ini disebabkan karena ayah bekerja penuh waktu dari pukul o7.0o pagi hingga sore bahkan malam. Dengan adanya smartphone, ayah dan anak dapat memiliki pola hubungan dalam sehari-hari. Pola hubungan ini dapat terjadi karena mereka menggunakan smartphone untuk berinteraksi ketika ayah sedang dalam periode waktu bekerja.

Mirabito dan Morgenstern (2004: 108) juga menjelaskan bahwa telpon selular merupakan salah satu perlengkapan dalam komunikasi yang digunakan untuk layanan komunikasi pribadi, termasuk smartphone. Hal ini mendukung temuan data yang mengatakan bahwa interaksi antara ayah dan anak langsung dapat terjadi melalui smartphone pribadi. Interaksi melalui smartphone pribadi ini menciptakan perubahan interaksi, yaitu sebelum anak menggunakan smartphone pribadi, ayah dan anak menggunakan telpon selular ibunya untuk mereka berinteraksi. Namun, saat ini smartphone sudah menjadi perlengkapan ayah dan anak dalam melakukan interaksi ketika ayah sedang bekerja, tidak lagi menunggu untuk berinteraksi secara langsung dirumah. Smartphone sebagai perlengkapan untuk berinteraksi antara ayah dan anak ini menunjukkan bahwa terjadinya pola komunikasi dari hubungan yang mereka lakukan. Sehingga, ketika anak telah memiliki smartphone sebagai layanan komunikasinya dengan ayah, membuat interaksi antara ayah dan anak tersebut menjadi lebih sering dibandingkan sebelum anak memiliki smartphone.

Perubahan interaksi antara anak dan ayah dengan penggunaan smartphone ini juga memberikan fungsi dalam memelihara hubungan interpersonal mereka dan memiliki potensi yang mendalam pada kedekatan ayah dan anak. Potensi yang timbul dalam interaksi menggunakan instant messenger seperti Whatsapp membuat mereka saling berdiskusi, bertukar informasi, serta meminta dan memberikan saran. Ketika smartphone digunakan oleh ayah dan anak untuk saling berdiskusi dan lain-lainnya, hal ini menunjukkan bahwa adanya pola komunikasi yang saling melengkapi dalam suatu keluarga. Ayah dapat menjalankan fungsi sosialisasi melalui 
smartphone untuk memenuhi kebutuhan anak dalam hal berdiskusi atau bertukar informasi. Berdiskusi, bertukar informasi, serta memberikan saran yang dilakukan ayah kepada anak juga menunjukkan adanya nilainilai yang diberikan ayah kepada anak dalam pola hubungan yang mereka ciptakan.

Teknologi komunikasi smartphone dianggap sebagai alat yang menciptakan efisiensi dalam berinteraksi. Efisiensi dalam berinteraksiini dibuktikan ketika anak menggunakan untuk keperluan perkuliahan, sementara juga efiesien ketika ayah menggunakan smartphone untuk keperluan bekerja sepertiaksesyahoo, gmail, group chat, dan lain-lain. Namun, ternyata smartphone juga memberikan efisiensi dalam merubah interaksi antara ayah dan anak. Hal ini dapat dibuktikan dalam pola hubungan yang tetap terjalin antara ayah dan anak ketika dalam periode waktu ayah bekerja. Dengan kata lain tidak ada lagi alasan interaksi ayah dan anak menjadi berkurang, karena smartphone tidak lagi menghambat jarak geografis antara mereka untuk saling berkomunikasi.

Dengan demikian, terjadinya perubahan interaksi antara anak dan ayah melaluismartphone dapat menunjukkan adanya pola hubungan antara mereka ketika ayah dalam periode waktu bekerja. Perubahan interaksi tersebut terlihat pada sebelum ayah dan anak menggunakan smartphone serta setelah menggunakan smartphone. Setelah menggunakan smartphone, ayah dan anak dapat melakukan interaksi tanpa harus menunggu untuk bertemu dirumah. Smartphone juga dapat digunakan oleh ayah dan anak untuk saling melengkapi ketika mereka merasa saling membutuhkan dalam hal berdiskusi, bertukar informasi, serta meminta dan memberikan saran. Sehingga, temuan data membuktikan bahwa memang terjadi perubahan interaksi antara ayah dan anak dengan berinteraksi menggunakan smartphone.

\section{Kontrol Sosial dalam Interaksi Ayah dan Anak Melalui Smartphone}

Perubahan interaksi yang terjadi pada ayah dan anak karena menggunakan smartphone ini menunjukkan bahwa ayah dan anak menjadi lebih dekat dan memiliki frekuensi berinteraksi yang lebih banyak. Kedekatan yang muncul karena smartphone ini membuat ayah bukan hanya memiliki fungsi dalam mencari nafkah saja, tetapi ayah juga dapat memberikan kontrol sosial kepada anak dalam interaksi melalui smartphone. Tidak hanya ibu yang mengontrol keseharian anak, tetapi ayah yang sedang bekerja juga dapat melakukan kontrol kepada anaknya melalui smartphone.

Frekuensi interaksi yang menjadi lebih sering dengan adanya smartphone ini salah satu hal yang mendukung ayah dalam memberikan kontrol kepada anak. Sebagian besar ayah menghubungi anak melalui smartphone untuk mengetahui keberadaan anak, kegiatan yang sedang dilakukan anak, mencari tahu anak sudah makan atau belum, dan mencari tahu kapan anak pulang dari kegiatannya. Selain itu, ayah juga bisa mengontrolanak melalui smartphoneapabila anak belum pulang dan sudah larut malam.

Menurut informan YM pada hari Jumat, 4 Desember 2015, apabila anak belum pulang dari kegiatannya, ia selalu menghubungi anak dan menyuruhnya untuk segera pulang. Ketika sudah malam dan anak belum pulang kerumah karena sedang melakukan aktivitas yang berhubungan dengan perkuliahan, ayah bisa memberikan toleransi pada hal tersebut. Tetapi, apabila sudah malam dan anak belum pulang karena alasan bermain dengan teman-temannya, informan YMpada hari Jumat, 4 Desember 2015 mengaku bahwa ia pasti tidak memberikan toleransi kepada anaknya. Hal ini disebabkan karena informan YM tidak ingin anaknya terlalu banyak main dan bermain hingga larut malam.

Apabila informan TS anak dari informan YM ini pulang terlalu larut malam, informan YM pasti menghubungi anaknya melalui smartphone dan menjemput anak jam berapapun. Karena menurut informan YMpada hari Jumat, 4 Desember 2015, lebih baik menjemput anak walaupun keberadaan anak agak jauh dari rumah dan sudah terlalu malam, daripada membiarkan anak untuk nginap dirumah temannya. Infroman YM ini sangat jarang untuk memperbolehkan anak 
nginap dirumah orang lain.

Hal ini juga dikatakan oleh informan TS pada hari Jumat, 4 Desember 2015, sebagai anak bahwa ia sudah terbiasa menghubungi ayahnya melalui smartphone untuk meminta dijemput apabila sudah malam dan tidak memungkinkan untuk pulang sendiri dengan kendaraan umum. Dengan demikian, informan YM dan TS mengaku bahwa memang kalau bukan karena smartphone, akan sulit untuk meminta ayah menjemput anak pada waktu tertentu. Hal ini terjadi pada anak informan YM yang perempuan, yaitu informan TS, berbeda dengan anak laki-lakinya.

Informan YM juga memperlakukan hal yang sama dalam mengontrol anak lakilakinya, yaitu apabila anak laki-lakinya nongkrong atau bermain hingga jam 1 atau jam 2 malam, selalu di hubungin oleh informan YM untuk meminta pulang kerumah. Menurut informan YM pada hari Jumat, 4 Desember 2015 di rumah informan, mengatakan bahwa:

"Walaupun anak saya itu laki-laki, tapi saya juga tidak terlalu suka dia main sampai malam-malam gitu. Nongkrong, main-main yang ga ada artinya. Saya tidak suka kalau anak saya banyak main. Karena kan juga kita ga tau diluar sana bagaimana. Diluar juga udah banyak kan kriminalitas di kalangan remaja-remaja gitu. Saya takut aja anak saya jadi terjerumus ya enggaengga. Jadi, kalau menurut saya anak saya sudah terlalu sering yang hampir setiap hari pulang tengah malam karena nongkrong, pasti saya langsung hubungi ke smartphonenya menyuruh si anak pulang dan pasti saya dengan nada marah"

Seperti yang terjadi pada informan YM, informan UR pada hari Sabtu, 5 Desember 2015, juga mengaku bahwa selalu memantau anak dengan menghubungi anak melalui telfon atau whatsapp. Informan UR Sabtu, 5 Desember 2015, juga mengatakan kepada anaknya informal LS untuk berhati-hati ketika sedang di jalan dan menuntut untuk jangan pulang larut malam.
Begitupula dengan informan SA, walaupun setiap pagi bersama anak untuk mengantar dan pulang bersama anak, informan SA tetap memantau anak dengan menanyakan kegiatananakmelaluiwhatsapp. Informan SA pada hari Selasa, 8 Desember 2015, menjelaskan bahwa ia mengirimkanchat kepada anak untuk menanyakan anak sedang menjalankan mata kuliah apa, menanyakan anak sudah makan atau belum, dan juga menanyakan anak kapan pulang. Karena informan SA selalu pulang dengan anaknya, apabila informan SA terlambat untuk pulang maka informan SA memberitahu kepada anak untuk menunggunya di kampus atau ditempat yang aman sampai ayahnya datang. Hal ini dilakukanolehanak dengan mengikuti perintah ayah untuk tetap menunggu sampai ayah datang menjemput.

Selain itu, anaksebagian besar mengikuti organisasi kampus. Menurut para informan, keikutsertaan anak dalam organisasi kampus membuat anak terkadang menjadi terlambat untuk pulang kerumah karena kegiatan organisasinya tersebut. Ketika anak harus terlambat untuk pulang kerumah karena kegiatan organisasinya, anak selalu memberikan kabar kepada ayahnya. Dengan demikian, ayah mengetahui kenapa anak tersebut harus terlambat pulang. Informan SApada hari Selasa, 8 Desember 2015, mengatakan bahwa apabila anak nginap dikosan temannya karena terlalu larut untuk pulang atau dituntut untuk datang pagi ke kampus karena ada acara, maka informan SA sebagai ayah tetap mengontrol anaknya dengan menanyakan melalui telfon atau chat dimana kosan temannya dan bersama siapa saja.

Ayah juga mengontrol anak dalam memilih organisasi atau Unit Kegiatan Mahasiswa (UKM) melalui smartphone. Informan NN pada hari Selasa, 8 Desember 2015, mengatakan bahwa pada awal masuk perkuliahan, ayahnya yaitu informan SA menghubunginya melalui smartphone dengan melarang NN untuk mengikuti salah satu Unit Kegiatan Mahasiswa yang berkaitan dengan agama di kampusnya dan melarang untuk mengikuti UKM yang sangat menyita 
waktu. Informan SA juga mengatakan bahwa apabila anak tetap ingin memilih UKM yang memakan waktu cukup banyak, maka anak tersebut harus dapat membagi waktunya sendiri untuk urusan perkuliahan lainnya. Dengan demikian, sebagai ayah selain berjuang untuk memenuhi keuangan keluarga, juga berusaha untuk mengontrol pergaulan anak.

Pendekatan fungsionalis menjelaskan bahwa keluarga sebagai organisasai sosial memiliki hirarki, yaitu ayah, ibu, dan anak yang memiliki fungsinya masing-masing dalam keluarga. Berdasarkan data yang ditemukan, ayah dapat memberikan kontrol sosialkepada anak dengan interaksi melalui smartphone ketika ayah sedang bekerja. Kontrol yang dilakukan oleh ayah dengan interaksi melalui smartphone ini merupakan harapan yang diutamakan oleh anak. Dari kontrol sosial yang dilakukan oleh ayah tersebut juga menunjukkan adanya pola hubungan komunikasi atau interaksi yang terjalin antara mereka melalui smartphone. Dengan kata lain, ayah dapat mengontrol perilaku keseharian anak ketika ayah dalam periode waktu bekerja.

Berkembangnya teknologi komunikasi sepertismartphoneinimerupakan perubahan yang dirasakan oleh masyarakat modern, seperti ayah dan anak yang juga mengikuti perkembangan teknologi komunikasi tersebut. Smartphone yang dimiliki oleh masyarakat kontemporer ini dapat membuat ayah dan anak saling mengontrol satu sama lain dengan pola hubungan yang mereka miliki, khusunya dalam interaksi (Grant dan Meadows, 2008:1), karena antara merekayang saling membutuhkan dan saling bergantung dalam kesehariannya. Dalam hal ini, kontrol sosial yang dapat dilakukan oleh ayah kepada anaknya melalui smartphone yaitu seperti menanyakan keberadaan anak, kegiatan yang sedang dilakukan anak, mencari tahu anak sudah makan atau belum, dan mencari tahu kapan anak pulang dari kegiatannya.

Ayah dan anak dalam menjalin suatu interaksi melalui smartphone disini memang terlihat saling membutuhkan dan saling bergantung satu sama lain. Hal ini disebut sebagai sistem dalam keluarga. Melalui smartphone,anak menghubungi ayah ketika anak kesulitan untuk pulang sendiri karena sudah malam dan tidak memungkinkan untuk menggunakan angkutan umum. Hal ini menunjukkan bahwa anak membutuhkan keberadaan ayah. Dengan kata lain, anak ketika sedang mengalami kesulitan seperti itu, sangat bergantung pada ayahnya dan mengharapkan ayah untuk menjemputnya. Harapan yang diinginkan anak tersebut dipenuhi oleh ayah dengan menjemput anak yang membutuhkan bantuannya.

Hal lainnya yang juga membuktikan bahwa anak membutuhkan dan bergantung pada kontrol sosial ayah yaitu ketika anak ingin pulang bersama ayahnya, sementara ayah berada pada kondisi harus pulang terlambat dari kantornya. Namun, anak tetap ingin menunggu ayahnya dikampus hingga ayah menjemputnya. Hal-hal seperti ini dapat mereka lakukan dengan adanya pola hubungan dalam bentuk interaksi karena kemudahan yang diperoleh dari penggunaan smartphone.

Aturan-aturan yang diberikan ayah berdasarkan pola hubungan dalam bentuk interaksi yang terjadi melalui smartphone ini, dapat membentuk pola perilaku anak. Berdasarkan data temuan menunjukkan bahwa sebagian besar ayah mengontrol perilaku anak melalui smartphone, seperti contoh untuk membiasakan anak tidak pulang terlalu malam. Apabila sudah malam dan anak belum pulang karena bermain atau nongkrong-nongkrong, ayah secara langsung menghubungi anak serta menyuruh anak untuk pulang. Hal ini dilakukan ayah dalam interaksi melalui smartphone dengantujuan agar anak dapat memiliki pola perilaku yang diharapkan oleh masyarakat. Aturan yang membentuk pola perilaku dalam masyarakat ini juga menunjukkan adanya suatu nilai-nilai yang diberikan ayah dalam interaksi melalui smartphone untuk dapat ditanamkan dalam diri anak. Sehingga, anak terbiasa untuk tidak pulang larut malam.

Selain itu, ketika ayah memberikan arahan terkait organisasi dan Unit Kegiatan Mahasiswa mana yang boleh atau tidak boleh 
dipilih oleh anak juga merupakan kontrol sosial ayah dengan menyampaikan aturanaturan serta nilai-nilai yang harus dimiliki anak. Apabila ayah tidak mengontrol anak dalam hal memilih organisasi dengan aturan dan nilai yang ditetapkan ayah, maka akan berpengaruh pada perilaku anak nantinya. Pemilihan organisasi ini dapat berpengaruh pada perilaku anak karena menurut salah satu informan, kegiatan-kegiatan yang dilakukan anak di lingkungannya dapat merubah sikap anak. Sehingga, ayah mengontrol perilaku anak dengan memberikan nilai serta aturan dalam pola hubungan interaksinya melalui smartphone untuk menghindari anak berperilaku menyimpang.

Oleh karena itu, dapat dibuktikan bahwa ternyata peran ayah sebagai kepala keluarga tidak hanya bekerja untuk memenuhi keuangan keluarga, namun dengan adanya kekuatan teknologi komunikasi seperti smartphone dapat membantu ayah mengontrol perilaku anak sehari-hari dalam interaksi melalui smartphone. Saling membutuhkan dan bergantung satu sama lain dapat terpenuhi dengan hubungan antara dan anak melalui smartphone dengan menerapkan nilai-nilai dan norma yang diberikan ayah. Dengan demikian, interaksi menggunakansmartphone dapat membantu ayah dalam mengatur dan mengontrol perilaku keseharian anak di masyarakat.

\section{Sosialisasi Ayah Kepada Anak Berdasarkan Interaksi Menggunakan Smartphone}

Teknologi komunikasi smartphone ini berfungsi dalam mensosialisasikan nilainilai bersifat mengingatkan yang ingin disampaikan oleh ayah melalui smartphone. Maksudnya, nilai-nilai itu muncul pada saat interaksi yang berlangsung antara ayah dan anak melalui smartphone danmengharuskan ayah untuk mensosialisasikan suatu nilai. Nilai-nilai yang dapat diberikan ayah kepada anak dalam interaksinya melalui smartphone antara lain nilai kemandirian, nilai tanggungjawab, dan nilai sopan santun.

Pertama, nilai-nilai yang disosialisasikan ayah kepada anak dalam interaksinya melalui smartphone yaitu nilai kemandirian. Informan SA pada hari Selasa, 8 Desember 2015, mengatakan bahwa melalui smartphone pernah memberitahu kepada anak harus mampu untuk mengambil keputusan sendiri dalam hal apapun. Informan SApada hari Selasa, 8 Desember 2015, berasumsi bahwa ketika anak mampu untuk mengambil keputusan sendiri, maka anak tersebut mampu berpikir hal mana yang baik untuk dipilih dan hal mana yang tidak baik untuk dipilih. Tuntutan informan SA kepada anak untuk mempu mengambil keputusan sendiri yaitu ketika anak menghubunginya dan anak merasa bingung untuk memilih tempat magang. Tetapi, informan SA pada hari Selasa, 8 Desember 2015, mengaku tetap memberikan bantuan kepada anak dengan membantu dalam hal mempertimbangkan lokasi, transportasi, dan bagus atau tidaknya tempat magang tersebut. Berbeda dengan informan UR, ia menuntut anak untuk mampu berpergian sendiri tanpa bergantung pada orang lain. Hal ini muncul dalam interaksinya dengan anaknya yaitu informan LS melalui smartphone ketika informan LS mengeluh kelelahan membawa kendaraan sendiri.

Kedua, nilai-nilai lain yang disosialisasikan ayah kepada anak melalui smartphone yaitu nilai-nilai bertanggungjawab. Menurut informan UR pada hariSabtu, 5 Desember 2015, ketika anaknya yaitu informan LS menghubunginya melalui smartphone untuk memberitahu bahwa terlambat pulang karena tugas organisasi yang belum selesai, maka informan UR memberikan toleransi dan mengatakan untuk menyelesaikan tugas organisasi tersebut dengan baik dan benar. Informan UR pada hari Sabtu, 5 Desember 2015, mengaku bahwa dengan ia memberitahu untuk menyelesaikan tugas dengan benar, agar informan LS tidak mengecewakan orang lain dan dapat bertanggungjawab atas tugasnya. Walaupun memang informan UR menyampaikannya tidak bersifat serius kepada anaknya. Seperti yang dikatakan informan UR pada hari Sabtu, 5 Desember 2015 di rumah informan: 
"Ya tapi saya ngomongnya pas di telfon itu engga serius-serius banget. Cuma gini aja, pas anak saya bilang baru bisa sampe rumah sekitar setengah 9-an soalnya kerjaan buat acara besok belum selesai. Terus saya jawab, yasudah kerjain dulu aja yang bener. Kalau udah selesai, pulang ya. Gitu...maksud saya kan kalau kerjaannya engga bener nanti orang jadi ga percaya lagi sama dia..."

Sementara, informan NN pada hari Selasa, 8 Desember 2015, mengatakan bahwa ketika awal masuk perkuliahan, ayahnya yaitu informan SA memberitahu kepadanya melalui smartphone bahwa dalam perkuliahan harus mampu untuk mengikuti organisasi di kampus, sehingga tidak untuk kuliah saja.

Selain itu, dalam interaksinya dengan anak melalui smartphone, khusunya dengan telfon, informan YM pada hari Jumat, 4 Desember 2015, mengatakan bahwa ia selalu mengingatkan anaknya yaitu informan TS untuk mengucapkan salam ketika memulai pembicaraan dan mengakhiri pembicaraan di telfon. Dengan kata lain, ayah juga dapat mengajarkan kepada anak untuk bersikap sopan walaupun menggunakan tekonologi komunikasi dalam berinteraksi dengan orang lain. Membicarakan masalah sosialisasi nilai tentang sopan santun, informan NN mengatakan bahwa ayahnya baik secara langsung maupun melalui smartphone, tidak memberikan nilai sopan santun tersebut. Namun, yang lebih sering melakukan hal tersebut adalah ibunya. Menurut informan NN pada hari Selasa, 8 Desember 2015 di FISIP UI:

"Biasanya tuh kalo saya mau ketemu orang di kantor mana, atau institusi mana untuk mencari tempat magang belakangan ini, pasti kan saya ngasih tau ke ayah saya dan ibu saya. Nah tapi kalau saya biasanya kasih tau ibu saya pas masih dirumah, terus ibu saya bilang ke saya berbicara sama orang yang sopan, yang baik, yang ramah. Tapi kalau sama ayah saya kadang lewat chat gitu kalau izin mau pergi untuk apply magang, ayah saya Cuma bilang yasudah hati-hati. Jadi ibu sih yang lebih sering ngasih tau hal-hal gini... terus biasanya yang mengingatkan untuk ibadah juga ibu"

Soe'oeddalamIhromi(2004)menjelaskan bahwa sosialisasi dapat dilakukan dalam jarak tertentu melalui sarana media, dalam hal ini yaitu media smartphone. Dalam artikel ini telah ditemukan bahwa teknologi komunikasi smartphone dapat memfasilitasi ayah untuk memberikan nilai-nilai kepada anak. Sosialisasi yang diberikan ayah muncul ketika interaksi ayah dan anak sedang berlangsung melalui smartphone. Sosialisai terkait nilai kemandirian, nilai bertanggungjawab, serta nilai sopan santun muncul ketika pola hubungan dalam bentuk interaksi antara ayah dan anak terjadi melalui smartphone. Nilai-nilai yang diberikan ayah melalui smartphone tersebut juga merupakan kebutuhan anak yang dapat dipenuhi olehayah dengan smartphone. Ayah dapat melengkapi kebutuhan anak dengan memberikan nilai-nilai ketika berinteraksi melalui smartphone.

Perspektif fungsionalis dalam membicarakan sosialisasi, dalam hal ini memberikan nilai dan norma kepada anak dalam interaksi menggunakan media perantara smartphone, dapat dilihat ketika ayah mengajarkan anak untuk mampu mengambil keputusan sendiri agar anak terbiasa untuk tidak bergantung pada orang lain. Sosialisasi tersebut tidak lagi terhambat, karena kekuatan smartphone yang dapat menjembatani interaksi antara ayah dan anak dalam menanamkan nilai dan norma. Nilai kemandirianyang diberikanayah kepadaanak dalam interaksi menggunakan smartphone ini dapat mempengaruhi perilaku anak di masyarakat. Hal ini dilakukan ayah untuk menanamkan pola perilaku yang tertanam dalam diri anak untuk yang dapat dijalankan ke dalam masyarakat.

Sementara, begitupula dengan nilai tanggungjawab yang diberikan ayah kepada anak dalam interaksi melalui smartphone, yaitu dengan ayah menerapkan nilai untuk selalu menyelesaikan tugas dengan baik, maka anak tersebut akan terbiasa untuk menyelesaikan tugasnya. Hal ini dilakukan 
ayah walaupun hanya melalui smartphone dengan tujuan agar anak dapat membawa perilaku tanggungjawabnya tersebut ke lingkungannya. Sehingga, anak dapat dipercaya oleh orang lain untuk dapat melakukan berbagai hal dengan baik.

Selanjutnya, membicarakan mengenai nilai sopan santun yang diterapkan ayah melalui smartphone dalam interaksinya, juga dapat berpengaruh pada kebiasaannya di masyarakat. Berdasarkan polahubunganyang terjadi melalui media smartphone, nilai sopan santun yang diterapkan ayah kepada anak disini yaitu anak diajarkan untuk mengucap salam. Penyampaian nilai sopan santun yang dilakukan ayah melalui smartphone tersebut membuat anak menjadi selalu mengucapkan salam ketika anak berinteraksi dengan oranglain maupun dengan orangtuanya melalui smartphone. Hal ini menunjukkan bahwa nilai sopan santun yang disampaikan ayah dalam interaksi melalui smartphone dapat terintergrasi dalam diri anak dan sudah menjadi hal biasa yang dilakukan oleh anak. Sehingga, nilai-nilai dan norma yang diberikan melalui pola hubungan yang berkaitan dengan interaksi antar ayah dan anak dapat berpengaruh pada perilaku dan komunikasi anak di masyarakat.

Interaksi melalui smartphone yang dilakukan oleh ayah dan anak juga dapat menjadi media perantara ayah untuk memberikan sosialisasi kepada anak. Sosialisasi nilai kemandirian, nilai tanggungjawab, dan nilai sopan santun yang muncul ketika ayah dan anak melalukan interkasi melalui smartphone menunjukkan bahwa adanya pola hubungan yang bekerja untuk saling melengkapi kebutuhan anggota keluarga. Dalam melengkapi kebutuhan anak tersebut, temuan data mengatakan bahwa ayah memberikan sosialisasi kepada anak berupa nilai-nilai serta norma-norma untuk mengontrol perilaku anak di masyarakat. Dengan demikian, sosialisasi melalui media perantara smartphone dapat dilakukan ayah kepada anaknya dalam suatu interaksi.

\section{SIMPULAN}

Keberadaan ayah yang diharapkan oleh anak dapat terpenuhi dengan adanya teknologi komunikasi smartphone yang memiliki kekuatan untuk dapat menjembatani interaksi anak dengan ayah ketika ayah berada dalam periode waktu sedang bekerja. Dengan menggunakan smartphone tersebut, dapat memberikan perubahan interaksi antara anak dan ayah, yaitu anak tidak lagi harus menunggu untuk berinteraksi dengan ayah ketika bertemu. Hal ini dapat dikatakan mengalami perubahan dalam berinteraksi karena adanya pola hubungan melalui smartphone yang dilakukan oleh ayah dan anak. Pola hubungan tersebut menjadisering terjadi ketika mereka menggunakan smartphone, dibandingkan sebelum menggunakan smartphone.

Fungsi ayah dalam keluarga memang tidak terlepas sebagai pencari nafkah untuk memenuhi kebutuhan keluarga yang dapat membuat interaksi dengan anak menjadi berkurang. Ternyata, dibalik itu semua juga dibutuhkannya fungsi ayah dalam hal mengontrol keseharian anak dan memberikan nilai-nilai kepada anak terkait kesehariannya dalam masyarakat. Kontrol sosial yang menjadi kebutuhan dan sesuatu yang diharapkan oleh anak dapat terwujud melalui interaksi menggunakan media perantara smartphone. Anak membutuhkan keberadaan ayah untuk berinteraksi dan bahkan untuk meminta bantuan kepada ayahnya. Dalam hal ini, anak tidak hanya membutuhkan kontrol sosial dari seorang ibu, tetapi juga membutuhkan kontrol sosial ayah dalam keadaan tertentu.

Smartphone dalam perannya sebagai perlengkapan komunikasi dapat membuat ayah melakukan kontrol kepada anak ketika ayah sedang bekerja. Anak membutuhkan keberadaan ayah untuk mengontrol kesehariannya dengan sekedar menanyakan keberadaan anak dan kegiatan yang sedang dilakukan oleh anak.Kebutuhan anak dalam hal kontrol dari ayah dapat terpenuhi ketika mereka memiliki pola hubungan melalui smartphone. Smartphone disini 
ternyata juga dapat menjadi perlengkapan komunikasi pribadi yang digunakan ayah untuk mensosialisasikan nilai-nilai kepada anaknya. Nilai-nilai yang dapat ditanamkan ayah kepada anakmerupakan nilai yang munculketika sedang berinteraksi menggunakan smartphone, antara lain nilai kemandirian, nilai bertanggung jawab, dan nilai sopan santun yang berpengaruh pada perilaku anak di masyarakat.

Smartphone sebagai teknologi komunikasi memberikan efisiensi dalam interaksi antara ayah dan anak. Efisien yang diberikan oleh smartphone ini adalah anak dapat menghubungi ayah kapan saja ketika ayah sedang berada pada periode waktu bekerja. Telfon pintar atau yang disebut smartphone inidapat memberikan kemudahan untuk ayah dalam berinteraksi dengan anak, mengontrol perilaku keseharian anak, dan memberikan sosialisasi kepada anak. Dengan demikian, smartphone yang digunakan oleh ayah dan anak sebagai peralatan komunikasi pribadi yang efisien dapat menjembatani interaksi mereka karena jarak geografis tidak lagi menjadi penghambat interaksi.

\section{DAFTAR PUSTAKA}

Astuti, Vera \& Puspitarani, Putri. 2013. "Keterlibatan Ayah dalam Pengasuhan Jarak Jauh Remaja”. Jurnal Fakultas Psikologi Universitas Diponegoro, hal. 121-131

Bryman, Alan. 2004. Social Research Methods 2nd Edition. New York: Oxford University Press

Eshleman, J. Ross. 2003. The Family Tenth Edition. United State of America: Wayne State University

Grant, August E. 2008. Communication Technology Update and Fundamentals 11th Edition. In Association with Technology, Futures Inc: Focal Press

Hidayati, Farida, dkk. 2011. "Peran Ayah dalam Pengasuhan Anak”. Jurnal Fakultas Psikologi Universitas Diponegoro, Vol. 9, No. 1

Ihromi, T.O. 2004. Bunga Rampai Sosiologi Keluarga. DKI Jakarta: Yayasan Obor Indonesia

Klein, David M and White, James M. 2007. Family Theories an Introduction. Sage Publications

Maharani, Orthorita Putri \& Andayani, Budi. 2003. "Hubungan Antara Dukungan Sosial Ayah dengan Penyesuaian Sosial pada Remaja Laki-laki”. Jurnal Psikologi Universitas Gadjah Mada, No, 1, 23-35

Mirabito, Michael M.A. 2004. The New Communications Technologies: Applications, Policy, and Impact Fifth Edition. With a Foreword by Mitchell Kapor: Focal Press.

Putra, Aucky. 2014. "Peran Smartphone dalam Interaksi Sosial Anak Muda”. Jurnal Fakultas Ilmu Sosial dan Ilmu Politik, Universitas Brawijaya.

Internet

Fatherhood Forum. Dilansir dari http:// 
fatherhood.id/tentang-kami/ dipetik pada hari Sabtu, 05 Desember 2015 pukul 09.15 WIB

Mardinata, Sulung Lahitani. 6 Alasan Anak Perempuan Dekat dengan Ayahnya. 2015. Dilansir dari http://citizen6. liputan6.com/read/2285016/6-alasananak-perempuan-lebih-dekat-denganayahnya dipetik pada hari Minggu, 27 Desember 2015 pukul 20:13 WIB

Purnomo, Sagita. Usia Terbaik Anak Menggunakan Smartphone. 2015. Dilansir dari http://lifestyle. a nalisadaily.com/read/usiaterbaik-anak-menggunakansmartphone/156008/2015/07/30 dipetik pada hari Minggu, 27 Desember 2015 pukul 20.29 WIB

Tarakanita Yogyakarta. Waktu Yang Tepat Anak Boleh Menggunakan Handphone. 2015. Dilansir dari http://yogyakarta. tarakanita.or.id/artikel/2015/04/22/ waktu-yang-tepat-anak-bolehmenggunakan-handphone-4dd5ae45. html dipetik pada hari Minggu, 27 Desember 2015 pukul 20.26 WIB

Wawancara dengan LS, anak, 5 Desember 2015

Wawancara dengan NN, anak, 8 Desember 2015

Wawancara dengan TS, anak, 4 Desember 2015

Wawancara dengan SA, ayah, 8 Desember 2015

Wawancara dengan UR, ayah, 5 Desember 2015

Wawancara dengan YM, ayah, 4 Desember 2015 